\title{
One Nation Over Coals: Cold War Nationalism and the Barbecue
}

\author{
Kristin L. Matthews
}

\begin{abstract}
"There is no doubt about it," House and Garden proclaimed in 1951, "America is barbecue minded." Barbecues dotted the news, advertising, and suburban landscapes of postwar America - evidence of what had become a $\$ 30$ million industry by 1955 and a $\$ 100$ million industry four years later. ${ }^{2}$ Popular periodicals like Look, Life, and The Saturday Evening Post announced America's embrace of outdoor cookery, exploring its role in promoting "the good life."3 Look's feature article "America Is Bit By the Barbecue Bug" announced "the taste for charcoal cooking has spread, moving eastward from the West Coast" such that "everyone is cooking outside."4 Evidence of barbecue's "spread" in the cultural consciousness of 1950 s America too could be seen in other print venues. "High-brow" periodicals like The Atlantic Monthly and The New Yorker published not only short stories, poems, and satires detailing America's love affair with the barbecue, but also pieces on the construction and execution of successful barbecues. ${ }^{5}$ News magazines Time, U.S. News \& World Report, Newsweek, and Business Week too examined barbecue's place in postwar America, counting corporate barbecues and a barbecue mob bust among newsworthy events. ${ }^{6}$ While women's magazines like McCall's, Good Housekeeping, and Parents' Magazine explored the domestic implications of barbecue, magazines targeting men, like Popular Science and Popular Mechanics, offered a wide array of building plans to help the American male construct his own barbecue. ${ }^{7}$ What these and scores of other articles touted was barbecue's role in creating a sense of home for in-
\end{abstract}


dividuals after World War II-as American Home put it, in postwar America, "home is home no longer sans a barbecue."

Although barbecue had long been part of American foodways - or as one critic of the "charcoal cult," John Willig, put it, "cooking outdoors is, of course, as old as man and a couple of dry twigs"-1950s Americans ravenously embraced barbecue. ${ }^{9}$ Barbecue was written about more in this decade than any other-over one hundred ninety-three articles appeared between 1950 and 1960 - and these texts reveal a postwar people trying to understand itself and its "home sweet home" in an uncertain world. ${ }^{10}$ If, as Roland Barthes argued in "Toward a Psychosociology of Contemporary Food Consumption" (1961), food is "a system of communication, a body of images, a protocol of usages, situations, and behavior" that reflects a "collective imagination showing the outlines of a certain mental framework," then postwar barbecue's images, practices, and philosophy can be read as indicators of American values, aspirations, and fears as they influenced ideas of self, nation, and other during this time of sociopolitical and cultural change. ${ }^{11}$ From 1945 to 1960 , America faced continued conflicts abroad with Europe's reconstruction, the emerging Cold War, and hot wars like Korea. The threat of communist infiltration undermined conventional notions of "us versus them" as the "them" were no longer readily recognized by nationality or uniform. "Them" could be anyone - it even could be "us"; thus, "Americanness" was a less stable marker of "friend" and "foe" than it had been, therein complicating efforts to identify others and one's self. The home front too witnessed significant changes as class lines shifted, educational and housing opportunities increased under the GI Bill, women continued to join the workforce, and racial divides became sites of conflict. Furthermore, within homes traditional gender divisions were troubled as women challenged conventional domesticity and heterosexuality became a fluid identity construct.

Understandably, many Americans struggled to find a source of stability or security among all of these changes, and barbecue appeared to offer just that. Barbecue extended a ready-made analogy to those seeking national fortification, for just as red meat's protein and iron nourished and strengthened the individual body, so too could its consumption fortify the body politic. On one level, domestic meat consumption was a propagandistic weapon in America's global war against communism as a symbol of democracy's bounty, fortitude, and might. Access to and selection of "choice" meat signaled capitalism's fruits - folk could own their own home, have leisure time to grill, and enjoy the freedom to buy the type of food they desired when they wanted it. On another level, barbecue as a practice and an idea spoke to traditional American values of individuality, ingenuity, family, community, progress, and pride. More than other leisure activities, roasting meat over an open fire evoked national myths of pioneering, manifest destiny, and American exceptionalism, inviting folk to participate and unite in a shared heritage. Accordingly, McCall's, the New York Times Magazine, and Look called barbecue "an American Art" and celebrated its ability to construct a solid foundation for communities as it "brings all America together." ${ }^{12}$ On yet another 


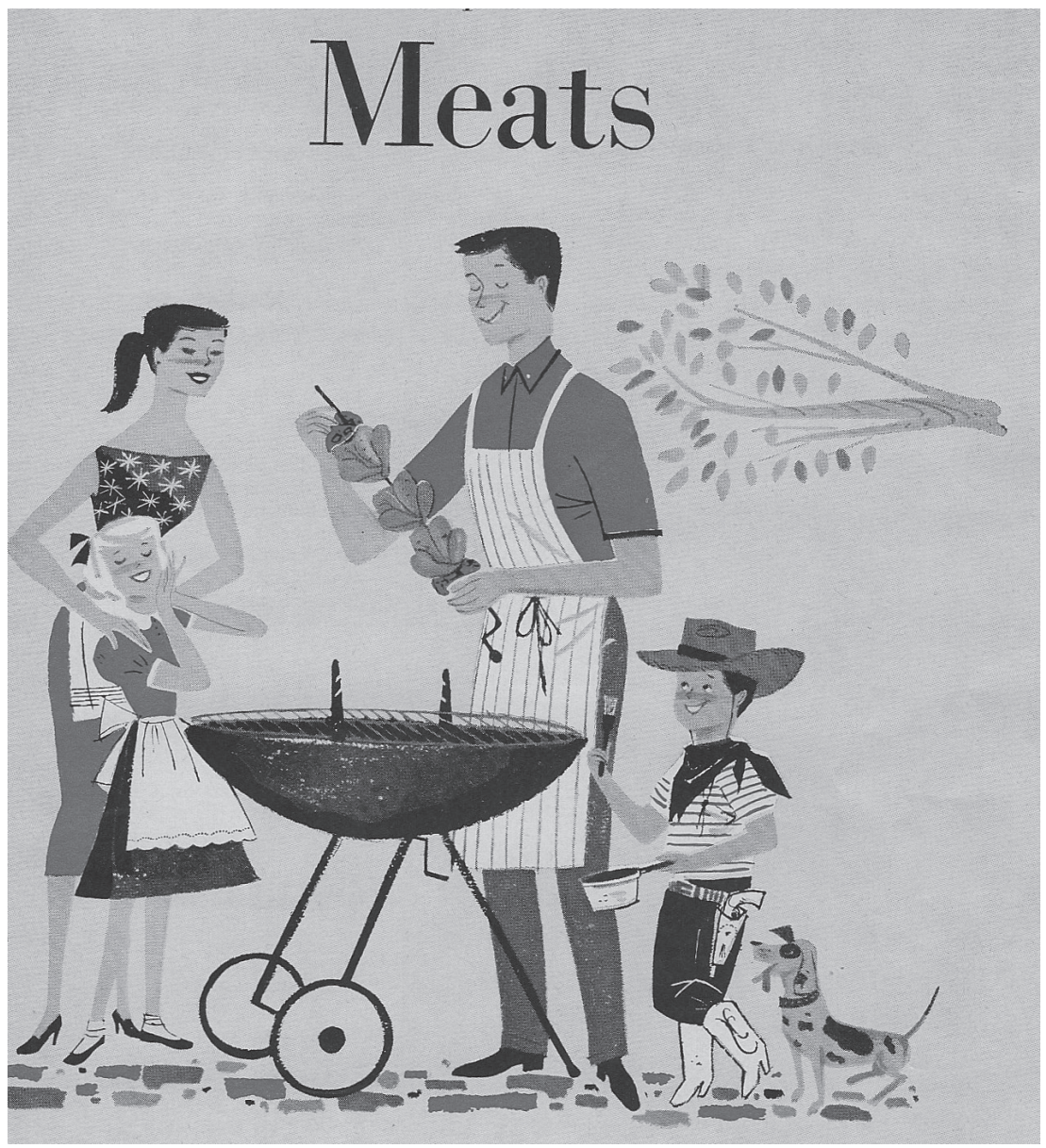

Figure 1: Happy Heteronormativity at the barbecue as depicted in the Better Homes and Gardens Barbecue Book. Image used with permission from Meredith Corporation, all rights reserved.

level, 1950s barbecue worked to "stabilize" the home in ways only it could, for barbecue's division of labor - "dad" is the chef whereas "mom" is on prep and clean-up duty — clarified gender roles and reasserted the postwar male's position outside in the public sphere as a hunter while repositioning females inside the private sphere to tidy the detritus of masculine labor and success (see Figure 1). To some extent, then, it was precisely because barbecue was "as old as man and a couple of dry twigs," that it could provide a sense of continuity and comfort to 1950 s Americans searching for a feeling of rootedness, or "at homeness," in traditional political, social, and gendered narratives.

Barbecue not only offered Americans refuge in a traditional and stable identity, but also served to fortify that very identity by excluding those elements 


\section{Kristin L. Matthews}

of postwar U.S. culture threatening to redefine the mainstream. Was the typical American family really as Reader's Digest claimed: comprised of an "average American male [who] stands five feet nine inches tall, weighs 158 pounds, prefers brunettes, baseball, beefsteak and French fried potatoes, and thinks the ability to run a home smoothly and efficiently is the most important quality in a wife" and an "average American female [who] is five feet four, weighs 132, can't stand an unshaven face, thinks husbands drink too much, prefers marriage to a career, but wants the word 'obey' taken out of the wedding ceremony"? ${ }^{13}$ Common sense and even minimal research says that, no, postwar Americans were significantly more diverse than the portrait Reader's Digest offered. This picture ignored or obfuscated 1950s America's considerable demographic, geographic, and ideological changes, as well as the anxieties those changes provoked. Barbecue culture similarly normalized an image of the American everyman that was neither racially nor economically diverse, but instead, a white, middle-class man seeking the good life. Barbecue ads, cook books, and news articles showed few women and no persons of color cooking barbecue, nor did they highlight grilling outside of middle-class suburban sanctuaries - unless, of course, it was the middle-class family on a picnic or a vacation in a national park. What 1950s barbecue culture served its target audience was a big helping of status-quo politics that both relied upon and forwarded an idyllic American dream that necessarily excluded some in order to privilege the rest. Nevertheless, the urgency and insistence with which barbecue culture proclaimed its status quo ideals signals an awareness of social change's inevitability and the reality of America's diverse and complicated body.

This article explores barbecue as a symbol of and vehicle for ideologies of nation, self, and other in 1950s America. Anointed an inherently American activity by advertisers, authors, and politicians alike, barbecue permeated the nationalistic discourse and socio-cultural consciousness of the immediate postwar period. As this article will demonstrate, barbecuing was much more than an act that provided family and friends with a tasty feast, it was a ritual that allowed postwar citizens to publicly perform Americanness as they strove to feel at home in the face of geopolitical and social instability. And like any ritual, barbecue promised its celebrants security, unity, and happiness in exchange for their fealty to particular national dogmas. Indeed, these efforts to find and feel at home over a bed of glowing coals relied upon and compulsively reiterated a conservative definition of citizenry as a response to or defense against the nation's rapidly changing socio-political demographics. Thus, 1950s American barbecue was a contested site, and an examination of its symbolic and practical function in postwar culture helps illuminate the period's problematic efforts to define, strengthen, and secure the body politic globally, nationally, and domestically in Cold War America. 


\section{0s Barbecue: Fortifying the Democratic Body}

In 1950s America, communism represented the ultimate threat to peace, prosperity, and the American "way of life." After World War II, America watched as the Soviet Union spread its influence across Eastern Europe and Asia. In 1946, Winston Churchill gave his famous "Iron Curtain" speech at Westminster College in America's heartland, voicing what many government, business, and popular leaders would soon echo: Communism was a powerful force that could undermine democracy and its freedoms if Americans weren't careful. Popular texts like Professor Kenneth Colegrove's Democracy versus Communism (1957) drew clearly defined battle lines between these two ideologies: democracy celebrated the individual, whereas communism propped up the state and demanded obedience; democracy allowed political participation, whereas communism denied political expression or plurality; democracy allowed free speech, whereas communism practiced censorship; democracy relied upon due process and judicial transparency, whereas communism allowed neither and instead relied on secrecy; democracy allowed one to own property, whereas communism ensured "no man's home is his castle"; and democracy allowed for free enterprise, whereas communism controlled its workers in the name of the state ${ }^{14}$ (see Figure 2). Opponents of communism warned that that system of government would deprive individuals of choice: where one lived, what one did, what one ate, whom one married, and how one worshipped. Americans would have to eschew the "good life" comprised of "plenty of food, enough serviceable and becoming clothing, and comfortable house or apartment to live in," in favor of communist deprivation, drudgery, and oppression. ${ }^{15}$ This idea of communism troubled postwar Americans; however, even more frightening was that the clear distinctions Colegrove and others drew between communist and democratic life did not hold up when used to identify communists themselves. President Dwight Eisenhower's Attorney General Herbert Brownell voiced this concern when he acknowledged that it is "almost impossible to 'spot' them since they no longer use membership cards or other written documents which will identify them for what they are." Tom Engelhardt's The End of Victory Culture (1995) and Robert Corber's In the Name of Nation Security (1993) extensively investigate the role that communism's shadowy presence played in ramping up postwar anxieties, but historian Ellen Schrecker put it most succinctly when she stated, "their invisibility increased their menace." 16 According to postwar public officials, no one was safe from the communist menace because it could be anywhere and anyone.

Fortunately, Americans had a weapon to help them preserve truth, justice, and the American way: barbecue. Or, at least, that is how barbecue culture promoted itself. 1950s barbecue advertised its ability to neutralize potential threats to and help uphold "American" values — values not coincidentally central to the government's fight against communism. First and foremost was barbecue's ability to bring "all America together" - symbolically through the shared act of working over a grill and literally through the social functions that revolved around a 


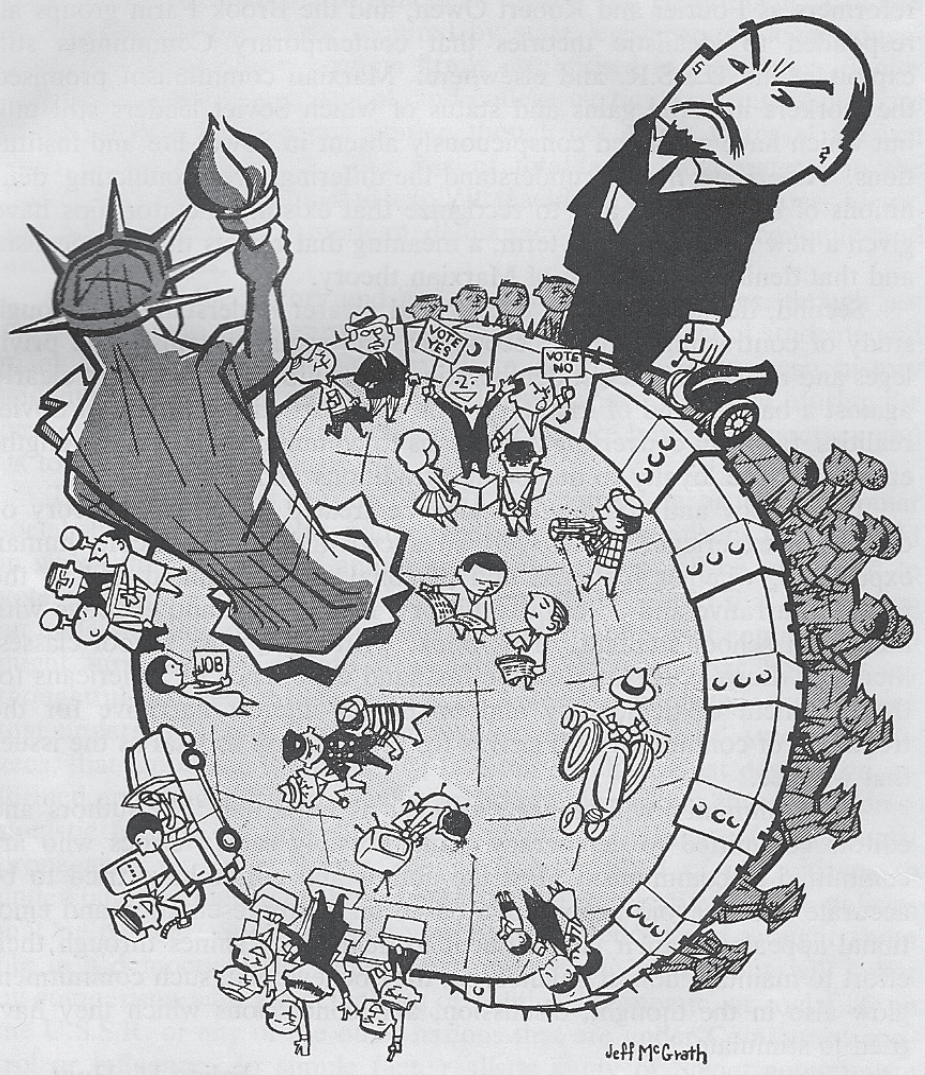

Figure 2: Ideology's iron divide as represented in Kenneth Colgrove's book Democracy versus Communism.

barbecue ${ }^{17}$ Various barbecue articles and books hinted that postwar Americans felt disconnected and insecure in this world of rapid economic, social, and geopolitical changes - feelings communists would capitalize on to garner recruits. Thus, they proposed an activity that united people in a common purpose and goal that wouldn't result in "dangerous" political organizing. Articles like American Home's "Cook-out U.S.A." showed pictures of teens and neighbors gathered for wholesome fun around the barbecue, as does Ellen Anger's Parents' Magazine article which announces that when "We Barbecue At Home," the family spends more time together, the kids are happier, and the home becomes a gathering place for family and friends (see Figure 3). Barbecue culture allowed folk to "feel right at home," to reconnect with family and friends, and to combat feelings of isolation that came with the rise in single-family dwellings. ${ }^{18}$ Big Boy Barbecue Cookbook suggests that barbecue is inherently unifying: "there's something of 


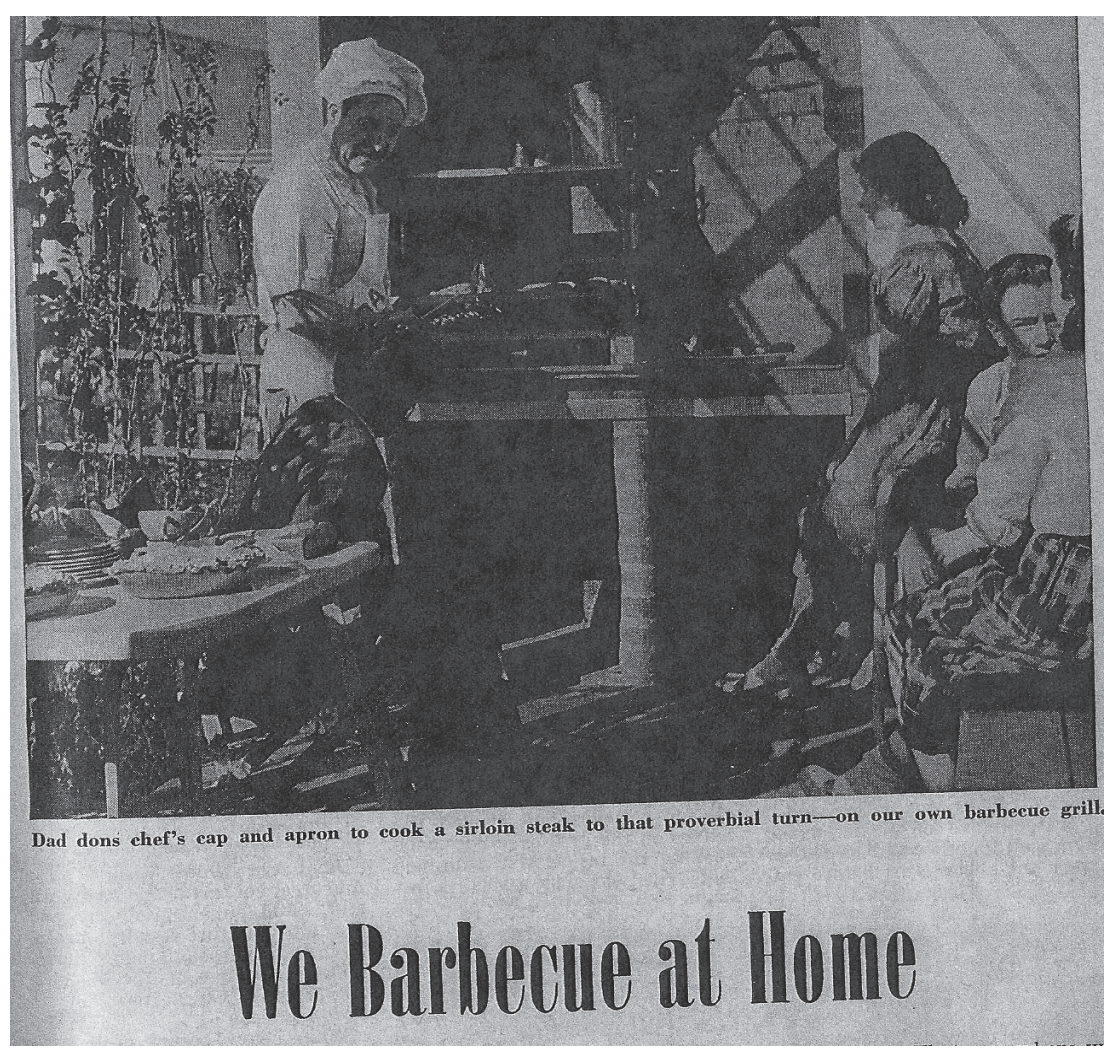

Figure 3: Marriage-strengthening and delinquency-preventing family togetherness at the barbecue as seen in Parents' Magazine. Photography by Mason Weymouth from F.P.S. Used with permission from Meredith Corporation. All rights reserved.

the rugged outdoorsman in every American - there's a feeling of adventure and good fellowship about a barbecue." 19 Unity's utility is also evident in Richard Rosen's charge that "the keynote of a successful barbecue is participation on a division of labor policy. One guest can be appointed bartender, another fire watcher, another server and so on. Nothing makes a successful party like making your guests feel important and needed." ${ }^{20}$ These calls echoed publications like the municipal government trade journal, American City, which counseled that "we're all in this together and ... the home front is a fighting front too. We must stand together with all our neighbors, with no fear, no panic, no confusion." 21 While postwar Americans are repeatedly reassured "we are strong," they are also told by James Conant that democracy's survival depends on "a high degree of national solidarity. Unless we are united, we shall fail." ${ }^{22}$ In this light, the barbecue that brings families, neighborhoods, and communities together and 
gives each individual a distinct job could be considered another weapon in the battle against dangerous elements seeking to undermine national stability.

Barbecue culture stressed that American unity was not to be confused with communist solidarity however, because, like the United States, it was comprised of disparate entities united in a common purpose. Hence, a key selling point of do-it-yourself projects like barbecue was that they allowed the individual to express himself, therein attaining or enriching the "good life." To this end Sunset, Better Homes \& Gardens, Popular Science, and Popular Mechanics offered countless barbecue patterns and blueprints, underlining the creative merits of do-it-yourself-work. It is telling that the article immediately following Popular Science's "Western Style Barbecue Tray" pattern asks readers, "What's Your Ingenuity Quotient?," for a central theme in these articles was individual ingenuity. Barbecue books promised that the barbecue chef, unlike communists who were controlled by the state or "organization men" who submitted their "other-directed" will to others, was his own person who designed, built, and used his barbecue just as he liked. ${ }^{23}$ Sunset's best-selling barbecue book provided over 50 pages of barbecue pit designs, but emphasized, "you don't have to follow them 'brick by brick.' Half the fun is calling your own ingenuity into play. Shift a detail or two; add a feature here; eliminate one there; so that when you're through, it's not 'just another barbecue,' but your own creation, the particular scheme that just exactly suits your needs." 24 "Creativity" was the watchword in many books linking ingenuity and individualism to the barbecue, because of which, "a man can really use his imagination - create." ${ }^{25}$ To underscore their point, authors John and Marie Roberson included several blank pages at the back of the book so the chef might be his own author. By repeatedly reassuring readers that they were individuals, barbecue culture emphasized postwar Americans' potential for creative authority and territorial mastery - traits markedly not communist.

Moreover, postwar culture aggressively argued that one of the ways in which individuals could express their American identity was through their consumer choices, therein preserving free-market capitalism. Lizbeth Cohen notes that as early as 1947, Life sounded the clarion call of what she has termed the "consumer republic": that it was one's civic responsibility to consume. ${ }^{26}$ This was most publicly displayed in Richard Nixon's 1959 "Kitchen Debate" with Khrushchev in which the vice president lauded new homebuyers and implied that consumerism was not only a right, but also every postwar American's duty in the fight against Communism. ${ }^{27}$ But Nixon was singing an old song, for twelve years earlier, a Life article, "The Price Problem," argued that the individual family's efforts to rise in the class ranks through consumption helped boost the economy and provide for the wellbeing of the nation as a whole, concluding the family "should buy more for the better living of others. ${ }^{.28}$ The article promoted a modern house with all of its conveniences that average folk "should be able to buy in order to provide full employment and improved living standards for the rest of the nation." ${ }^{29}$ Such feature articles issued multiple implicit commands: not only "should" the reader 
want this life, but he should want to want it, and should do so for the good of the nation.

Other pieces equated homeownership and its trappings with democracy, security, and civic virtue more explicitly. For instance, "Everybody Can Own a House," praised recent housing laws that have "given the Little Man the same access to the big-time money market," stating of the Little Man, "he's us." ${ }^{30}$ Parents' Magazine echoed this praise, asserting that homes "are investments in better living, in the sense of independence ... in the opportunity to mow your own grass, fix your own faucet, plant your own lovely flowers or decorate your rooms exactly as you please." Because the Little Man has access to "property," he gains access to all the freedoms that come with that newfound "independence," and as a result, "the civic virtues flourish. Millions of people for the first time pay local taxes, look into local government and take a hand in it." These authors reframe American independence and manifest destiny in terms of home ownership and domestic security: choosing and buying one's own home helps strengthen democracy, which helps secure the nation, which ensures that others can choose and buy a home, and so on. Thus, homeowners were "the backbone of the community." ${ }^{31}$ Nation's Business too put world peace on their shoulders, contending "that rising home ownership should produce more stability, more responsibility, less adult and juvenile delinquency, and a generally better world." The magazine quipped that because of the boom in second cars, new asphalt, "barbecue pits dot[ting] the landscape," and so on, "Communists are unhappy; but crabgrass never had it so good." ${ }^{\prime 32}$ Despite the joking tone, the authors earnestly believed that buying into a suburban version of the American dream safeguarded the economic system upon which it is built: capitalism. Mass housing builder William Levitt too underscored such when he famously remarked, "no man who owns his own house and lot can be a communist. ... He has too much to do." ${ }^{33}$ According to Levitt, home ownership, upkeep, and leisure-time enjoyment were markers of good citizenship because they anchored people in key tenets of Americanism: the pursuit of property and happiness.

Barbecue was part of the work that gave folk "too much to do," for between the planning, building, accessorizing, testing, and using of the barbecue, postwar Americans had their hands full. They had no time to read radical literature, go to meetings, or organize with communists because they were focused on more important work: keeping vigilant watch on the "suburban garden or back yard," "back yards and patios from coast to coast," and the "suburban wild life." ${ }^{34}$ Sunset, Better Homes \& Gardens, and American Home filled their summer issues with patterns, plans, and photos of barbecues that one could build in one's yard such that one could not flip through a magazine without stumbling across "Here's a Dandy Barbecue Pattern!" "Here's A Barbecue With the Comforts of Home," "Knockdown Barbecue," or "What's Cooking with Barbecues? 12 Barbecues You Can Build." Even "high-brow" publications like Atlantic Monthly extolled the virtue of building one's own barbecue - or knowing who to hire so that "his experience and my originality made it an outstanding success." 35 


\section{Kristin L. Matthews}

Work was what made barbecue "dandy," "knockdown," and a "party," and it was that which provided one with the security that came with the "comforts" of home. Significantly, many of the images accompanying instructions on barbecue construction and equipment used bears striking resemblances to weapons and implied an urgency to protect America. Both of Sunset Magazine's barbecue books either employed militaristic rhetoric, calling chefs "veterans," or used militaristic iconography, depicting the chef's gear as nuclear arsenal: the salt and pepper shakers are shaped like bombs, the spatula and tongs are mapped in an "x-marks the spot" fashion, and the chef's hat resembles a mushroom cloud (see Figure 4) ${ }^{36}$ Security manifested in other aspects of barbecue culture. Arthur Schlesinger, Jr. indicated meat was an anti-communist weapon in his 1945 essay "Food in the Making of America"; Bob Stahr used military terms to describe "Operation Barbecue" - "a major campaign" waged by his "whole family" to build a backyard barbecue; and Harold Bartron's barbecue equipment included materials straight out of the atomic laboratory - "an indicating pyrometer which has been used to check thermonuclear readings and heat temperatures." ${ }^{\prime 7}$ The common thread among these texts was that one did this work because it is fun, but the common subtext was that one should do this work because it helps fortify one's home and community.

Although these texts attempted to communicate America's strength and security, the repeated "do, or else" imperative unintentionally signaled an anxiety that America's "one nation" wasn't so "one"- that within the "us" was a multiplicity that couldn't be molded easily into a singular, united body to fight "them" - even with a spatula and tongs. Ironically, repetition of claims like "we must stand together with all our neighbors, with no fear, no panic, no confusion," was meant to instill camaraderie and confidence in national defense, but the excess and pathos of such made it seem as if attack was inevitable. ${ }^{38}$ Thus, one could argue that while barbecue culture promoted itself as a weapon against communism, its insistence on this "necessary" function also worked to reinforce the anxiety it was attempting to ameliorate in the first place.

\section{Serving Up Barbecue and American Identity}

Barbecue culture not only offered itself as an instrument of foreign policy, but also worked to secure the home front in the face of social change. Sales figures and publication records indicate that postwar Americans ate up barbecue and what it represented - a way of life marked by leisure, abundance, and freedom, or the good life. In March 1947, Life put out a special issue dedicated to and entitled "the good life," reporting that "zestful Americans enjoy their new leisure," arguing "leisure is the purpose of work," and detailing various benefits of postwar America's play, including a strong economy, individual expression, and "a better civilization." Life went so far as to make a direct correlation between types, frequency, and quality of a nation's leisure and the "level of its civilization," and in so doing, the issue's 100 plus pages proposed that how Americans tabulated 


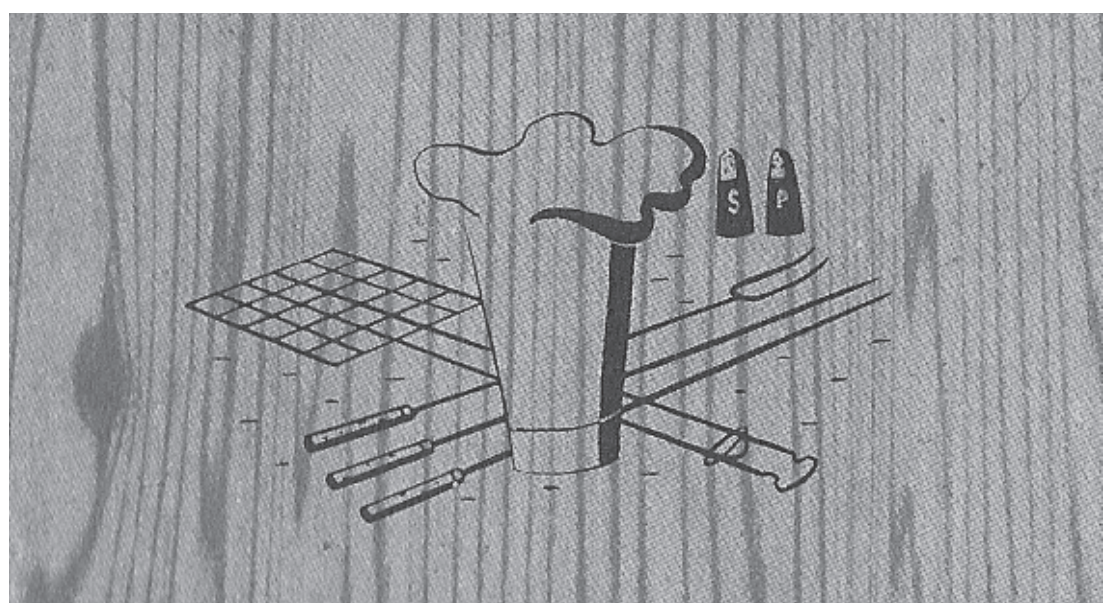

Figure 4: The postwar American's barbecuing arsenal—deployed to ensure domestic and national health. Used with permission from the Sunset Publishing Corporation.

the " $\$ 40$ billion bill just for Fun" determined just what America was. Although Life hailed this as a new leisure, it also spun it as the American dream realizedas the actualization of an idea first conceived of by "the founding fathers . . . [who] set things up that way." ${ }^{39}$ Both new and old, this leisure ideal was doubly "American" because it magnified "founding" principles and it illustrated notions of progress at work. Life held up "the good life" as an ideal towards which all Americans should strive, predominantly featuring those from the leisure classes and promoting aspirations of social mobility central to the American dream. It even featured "Good Uses of Their Spare Time by Celebrated People," picturing author Katherine Anne Porter baking, nuclear scientist James Van Allen building toys in his workshop, and U.N. undersecretary Ralph Bunche gardening. These activities were performed at home by "celebrated" American figures, encouraging emulation and indicating that pleasure, success, and patriotism comes from consumption on the home front. ${ }^{40}$

Crowing, "chicken barbecue sounds as American as Fourth of July," postwar periodicals devoted substantial print to this facet of American leisure. ${ }^{41}$ In fact, few activities typified the new American leisure like barbecue for it was located at and celebrated home and home ownership, it advertised the abundance found in postwar America, and it promoted consumption as one's patriotic duty. According to the New York Times, barbecue was the new leisure, for it "stands for feast and fun," and is in part a sport, a creative act, a symbol of plenty, and a marker of the freedom from work. ${ }^{42}$ Like other leisure activities, barbecue was scaled back during the war because of food rations and because "nowadays such equipment is hard to come by." ${ }^{\prime 3}$ American periodicals were short on barbecue articles during this period. Ripley Golovin Hathaway notes that the number 
of published articles on barbecue hit a low of five between September 1941 and September $1945 .{ }^{44}$ After the war's end, however, middle-class Americans could return to and improve upon what Laura Shapiro has called "traditional cooking. ${ }^{\prime 45}$ Although Shapiro's discussion of traditional postwar foodways and gender focuses primarily on women and their resistance to convenience foods, her argument can be extended to postwar men as well, for after years of sacrifice, American men too found comfort in familiar food rituals that confirmed established notions of self, family, and community—rituals that included barbecuing. Meat was at the center of this "good-food era," more specifically, beef- - "King of American Meats" - which had dethroned pork as America's meat of choice by $1960 .{ }^{46}$ Moreover, beef was a symbol of "Americanness" to its consumers, conjuring cowboys, expansionism, and the western frontier: "steak is the favorite food of Americans of all ages, both male and female, and has been ever since the first prime steer came off the mid-west ranches. ${ }^{~} 47$

In pronouncing its Americanness, 1950s barbecue culture invoked originary narratives like that "first prime steer" to claim the good life as America's inheritance and to reinforce traditional ideals in which folk could find meaning, place, and security in uncertain times. Just as Life pronounced leisure a component of the founding fathers' vision, so too did other postwar texts tie leisure activities like barbecue to America's beginnings and bedrock ideals: freedom, democracy, and unity. James Beard's contribution to House \& Garden's "Barbecue Cook Book" issue appeals to these narratives, postulating that, "Probably the first genuinely good meal the Pilgrims had in this country was a fresh-killed turkey, spitted and roasted-barbecued." Beard places early Americans' first taste of freedom on the barbecue, binding it to America's genesis..$^{48}$ Others traced barbecue's later lineage, emphasizing its role in democracy's development and contending that the United States rose not just from revolutionary ashes, but also from barbecue coals. Look relates how "American barbecues used to be outdoor community feasts at which political candidates were heard against a background of sizzling animals" to assert the connection between meat and America's political evolution. ${ }^{49}$ John and Marie Roberson's The Complete Barbecue Book (1951) also named barbecue's place in America's political history, acknowledging, "to most of our forefathers, North, South, East, or West, barbecue suggested a large outdoor gathering. Political speeches and a band were as essential as the feast of roasted meats." ${ }^{50}$ These sources pair barbecue and America's democratic heritage, indicating a co-evolution of sorts that connects barbecue not only to what is American, but what is America. ${ }^{51}$

At the same time, barbecue celebrated another facet of American progress: the immigrant narrative. Many articles and recipes granted that America was not just pilgrim in origin, but was comprised of native peoples as well. For example, Harold Barton's Barbecue it Right! (1953) contended "the Indian shown on the cover, using a forked stick and a bed of coals, could cook meats with more and better flavor than the white man who came to the country can yet cook on or in his fancy stoves," acknowledging lessons to be learned from America's native 
ancestors..$^{52}$ Others were quick to point out barbecue's Spanish ancestry in California. Chef Jim Beard's Complete Book of Barbecue and Rotisserie Cooking (1954) explicitly rooted American exceptionalism in multiple cooking traditions: "America has the world's greatest heritage of outdoor — and barbecue - cooking lore. To the old-fashioned methods of our pioneer settlers, we have added the wonderfully varied approaches of our Mexican and Latin-American neighbors and of our citizens from every nation in the world." ${ }^{53}$ Beard reveres America's "melting pot" ideology as it magnifies the nation's expansiveness, opportunity, and plurality which combined to form a unique unity. Many magazines and books included Polynesian, Mexican, Korean, Japanese, and other barbecue recipes to celebrate the diverse flavors and traditions brought to and included in American outdoor cookery. These traditions and minority populations did not seem part of 1950s racial unrest, and therefore, safe to recognize without endangering the status quo. Certainly, barbecue exposed Americans to different food traditions they may not have experienced otherwise and expanded the notion of America and American to recognize an additive dimension derived from "our citizens from every nation in the world." While not wholly inclusive by twenty-first century standards, these texts did argue that both barbecue's and America's flavor relied upon diversity, which represented America's exceptionalism. In so doing, they demonstrated that change was the norm, and it had and would continue to make America great.

Barbecue also allowed the United States to honor its unique pioneering heritage and the traits it fostered - individualism, determination, adventurousness, hope, and true grit—reinforcing America's uniqueness and exceptionalism while simultaneously asserting that its pioneering spirit lives on. Paul Swensson fetes barbecue as "the only type of cooking available to the western pioneers as they crossed the plains and mountains; the only type of cooking available to the 'tall man in the saddle'," and the Tested Recipe Institute too narrates barbecue's origins as being of "pioneers, cowboys, and hunters" in their intro "How it All Began," drawing a direct correlation between barbecue's development and America's westward expansion. ${ }^{54}$ "Manifest destiny" claimed land, property, exploration, and the potential for economic increase as a divine mission and right, and barbecue culture embraced this "right," claiming that the right to move was the freedom to grill, and that America had and always would possess "open space" and new frontiers for exploration. Look typified this when it asserted that "the taste for charcoal cooking has spread, moving eastward from the West Coast. ${ }^{{ }^{55}}$ Like America in its pioneering days, barbecue spread from east to west, replicating the extension and creation of the diverse United States as it conquered new terrains, added new folk, and incorporated new traditions into its body. If barbecue evolved with democracy, then the spread of barbecue was inseparable from the spread of democratic principles and institutions in postwar people's minds.

In fact, these periodicals pronounced that the democratic ideal was real - that any person could make it in America - and proposed that barbecue could help. 
For example, the Big Boy Barbecue Book (1956) claims that cooking with smoke used to be just "for the landed gentry"; however, now, thanks to grill makers like Big Boy, cooking with smoke provides fun for all. The barbecue book as a whole praises the democratization wrought by barbecue cooking, praise echoed in the Sunset Barbecue Book, which proclaims "anybody can be a barbecue expert." Barbecue pledged equal success and glory to all men who stepped behind the barbecue; yet, Trader Vic voiced explicitly the implication that those who succeed as a grill master also will achieve glory beyond the grill: "I have become firmly convinced that if a man is successful in one field he can be so in another, if he so wishes. ${ }^{" 56}$ Trader Vic and others compulsively restate this promise, attempting to convince barbecue chefs (and perhaps themselves) that the American dream's social mobility isn't a dream, but a reality available to those who are willing to grasp it.

Key to this success was the material abundance postwar Americans enjoyed. While many barbecue plans like Architectural Record's stressed their use of "no critical materials" needed in wartime and immediate postwar industry and emphasized instead the abundance of brick and concrete necessary to construct a solid barbecue, ${ }^{57}$ others reveled in the eased building restrictions, announcing that "materials are plentiful" in the postwar housing boom, as was space for those part of the exodus into the suburbs, or the "rebellion against feeling cramped." 58 As such, they typify what Arthur Adams, President of the American Council on Education, said in 1952: "our nation is vast, powerful and richly endowed by nature, our people are both numerous and capable." Adams' hopeful hyperbole was reinforced by market changes, for during the 1950s, America's GNP almost doubled, due in part to the "nearly a half-trillion dollars' worth of goods and services" purchased on the home front. ${ }^{59}$ Having a yard of one's own, access to funds and the best supplies, and leisure time to build a barbecue signaled that one had made it, or had arrived at one manifestation of the American dream. Postwar barbecue purveyors shouted from the rooftops "we have, in this country, the best foods available to any nation in the world. In no other country does the communications system permit the distribution of food on a scale possible here. Refrigeration, as we know it, does not exist elsewhere in the world." ${ }^{\prime 60}$ And, as Andrew Dunar demonstrates, they were right: "Americans consumed an average of 3,186 calories a day, whereas even comparatively prosperous Europeans consumed between 2,000 and 2,700." ${ }^{\circ 1} 1950$ s barbecue claimed that not only was America back, but it also was better than ever, and it argued that the dream of social mobility was within the American everyman's reach.

This ascension was contingent upon property acquisition. "Even more than automobiles and refrigerators and washing machines, homes are what America is eager to be able to buy," Harry Binsse notes in a 1945 Commonweal article, stressing that folk yearn "for the day when we can have some slight choice in where and how we live." ${ }^{\prime 2}$ Congress heeded the cry passing in 1948 legislation that eased the mortgage market and extended home ownership and choice to new populations at rates previously unknown. The VA and FHA offered GI loans, 
and these programs were so successful such that "families headed by World War II veterans dominated the new housing market." ${ }^{\prime 3}$ According to the Bureau of Labor Statistics, owner occupation statistics rose from 47.4 percent in 1944, to 50.2 percent in 1945 , to 52.6 percent in 1947 , to 53.4 percent in $1950 .{ }^{64}$ In 1951 , 55 percent of houses were owner occupied, a historic high since census data was first collected ${ }^{65}$ Most buyers in the late 1940s and early 1950s were of the middle-income group and most bought homes with low-equity and high-ratio loans, 80 percent of which were either FHA or VA loans in 1950-1951. ${ }^{66}$ Government legislation and economy expansion building helped locate the "heart" of postwar America in the suburban home. For the middle class, the home signaled both social mobility and the stability in being part of and an inheritor to a storied legacy won by early pioneers, a legacy of unity and rootedness.

While the American dream's ideal of home, social mobility, material abundance, and individual expression were promised to all, not everyone could attain it. African Americans and other ethnic groups were underrepresented in postwar leisure culture depicted in Life, Look, and the New York Times. Racially restrictive covenants, discriminatory hiring, and segregation limited social mobility mostly to whites. If Levittown symbolized the American dream, then its rejection of non-whites represented the exclusionary racial dynamics of postwar economics and culture. As Kenneth Jackson's Crabgrass Frontier (1985) and Andrew Dunar's America in the Fifties (2006) have demonstrated, Levitt's aim to get all Americans into a home was restrictive - there were no blacks among Levittown's 82,000 residents. When confronted, Levitt remarked that "we can solve a housing problem, or we can try to solve a racial problem. But we cannot combine the two." ${ }^{97}$ In Detroit, Chicago, Atlanta, and Los Angeles, bombings, demonstrations, and assaults on blacks attempting to move into predominantly white neighborhoods were on the rise. Stephen Meyer notes in As Long As They Don't Move In Next Door (2000) that between 1956 and 1958 there were over 250 reported incidents of racial violence in Chicago alone. Baseball great Willy Mays struggled to find a home in San Francisco after the Giants' 1957 move there from New York, and once he did, his family was welcomed to the neighborhood by a rock thrown through their front window. ${ }^{68}$ The Federal Housing Authority codified racially restrictive covenants to prevent "inharmonious racial groups" from entering into white neighborhoods, claiming, "if a neighborhood is to retain stability, it is necessary that properties shall continue to be occupied by the same social and racial classes." ${ }^{99}$ As illustrated by Lorraine Hansberry's award-winning play A Raisin in the Sun (1959), systemic, institutionalized, postwar racism consistently denied minorities the dream of home ownership, individual expression, and the fruits of their hard work.

Given the stifling separate but equal politics of segregation in 1950s America, it is not surprising that African, Afro-Caribbean, and African American barbecue traditions would be largely absent from barbecue culture despite their significant contribution to America's barbecue heritage. Southern barbecue culture, in particular, was derived largely from African slave traditions of roasting meats. 
Because slaves were the primary cooks for middle and upper-class Southern whites, their food traditions were absorbed into a larger Southern food culture. ${ }^{70}$ One could argue that 1950s barbecue culture believed that it had moved beyond these divisions. Or perhaps this absence was due to a part of America's heritage that barbecue culture did not wish to emphasize: how does one speak of African American barbecue traditions without invoking slavery? Most likely, however, African American barbecue traditions went unnamed because they had already been appropriated by white cooking traditions without recognition of their particular origins.

Similarly, even as barbecue culture identified traditions and extolled influences of native and immigrant others, it often came up short as differences were celebrated not necessarily in and of themselves, but insofar as they elevated Anglo American traditions. A troubling rhetoric crept into some texts that gathered diverse peoples and cooking methods under the umbrella of "American," for they seemed to assume that whiteness was the norm into which different cultural, racial, or ethnic histories were melted. Returning to Beard, his text appears to co-opt indigenous persons and traditions when he adds them to "the old-fashioned methods of our pioneer settlers," granting cultural primacy to America's Anglo explorers even though they came second. ${ }^{71}$ Recent scholarship, José E. Limón's Dancing with the Devil (1994) and L. Eric Elie's collection Corn Bread Nation 2 (2004), for example, have challenged this appropriation, revising American barbecue's origin tale both to reflect its multicultural roots and to demonstrate how particular groups retain distinct barbecue traditions in spite of mainstream barbecue culture. Nevertheless, in the 1950s, ethnic foodways were oftentimes a tool for Anglo American progress. For instance, the Robersons announce, "today we can cook with the gusto of native past masters, use their recipes, now much improved, and enjoy barbecuing of a character and excellence they could never have known." ${ }^{72}$ Here American ingenuity takes native past masters and improves on them, with the Robersons implying one can do so because American culture is more advanced, and consequently better. Although postwar barbecue tried to balance ideas of old/new and native/pioneer, and although they did recognize various ethnic traditions as part of "American culture," oftentimes they did so in a way that romanticized the primitive and Anglo American conqueror. While barbecue's new "mastery" of old traditions reflected an attempt to open America's food heritage to other traditions, it couldn't yet fully reconcile America's early heritage of ethnic conflict and slavery.

At times the barbecue industry also seemed to demand a unity within its privileged white, middle-class demographic that was less individualistic than it was uniform. Like bestsellers The Organization Man (1956), The Affluent Society (1958), and The Status Seekers (1959), barbecue culture voiced concerns that the American individual was losing his sense of distinct self. Thus, it directed much of its pitch towards barbecue's role in safeguarding individualism, promising "there are few rules to follow in grill cookery. What's easiest for you, and tastes best, is right." "73 Yet, too often these claims read more like an advertising strategy 
of an industry that relied upon mass consumption for its very existence than a legitimate worry about the individual's place in a mass culture society. As noted previously, articles, ads, and recipes alike stressed the ways in which barbecue allowed the individual to express himself and combat conformity as discussed in David Riesman's "The Suburban Sadness" (1958), tapping into this psychology to move products. ${ }^{74}$ However, this individualism was a commodity dependent upon the acquisition and mastery of particular goods and behaviors. Furthermore, individualism was reliant upon experts - those who could help individuals be their best. Barbecue culture's experts taught chefs how to purchase the best equipment, find the best meats, follow the best recipes, and cook the best meals; "you" may be the boss, but the expert is the ultimate authority. The scientism and specialization that Whyte's The Organization Man associated with postwar America's social homogeneity were evidenced in and validated by the barbecue industry's eagerness to demonstrate its proven quality with books like Big Boy Barbecue Book and The Hungry Man's Outdoor Grill Cookbook published by the Tested Recipe Institute and the Culinary Arts Institute, respectively. ${ }^{75}$ These texts asserted that it was not the individual grill master who best determined what constituted good barbecue and, by extension, a good barbecuing man, but a battery of culinary scientists, boardroom executives, and advertisers. Magazines too published articles by the experts, relying on James Beard, Trader Vic, or Charcoal Charlie to make professionals out of barbecuing amateurs and sell some product along the way, the primary product being the barbecuing man.

Understandably, many postwar thinkers cringed at the equation of national, social, and individual security with the consumption that barbecue signified, warning that the postwar period's economic growth seemed to be based less on a pragmatic system of choice than on a coercive commercialism that exploited postwar insecurities. For example Vance Packard's The Hidden Persuaders (1959) argued that these concerns were both the vehicle for sales and the product being sold, for the advertisers of mass consumerism moved more goods by "successfully manipulating or coping with our guilt feelings, fears, anxieties, hostilities, loneliness feelings, inner tensions." Advertisers invited consumers to buy into these fears as a lived reality that only could be ameliorated with goods. Historian Elaine Tyler May's Homeward Bound (1988) concurs, demonstrating how "consumerism in the postwar years went far beyond the mere purchases of goods and services. It included important cultural values such as patriotism and security, demonstrated success and social mobility, and defined lifestyles." Segmented marketing identified and magnified these concerns in specific groups, prompting economist John Kenneth Galbraith's discussion of how "every corner of the public psyche is canvassed by some of the nation's most talented citizens to see if the desire for some merchantable product can be cultivated." "77 If purchases were prompted by fears of exclusion or instability, then consumption, which promised to yield security, in fact relied upon national insecurity to perpetuate and sustain the economy. 
Key to facilitating this "sale" was barbecue's role as a status symbol in 1950s suburbia. Folk didn't heed Sunset's charge not to "build an elaborate affair just to show the Joneses a thing or two," because a bigger barbecue with better gear signified greater social capital. Hence, barbecuing became a show akin to C. Wright Mills" idea of "prestige" - a performance that "involves at least two persons: one to claim it and another to honor the claim," and relies upon public displays of consumption or mass leisure activities, ensuring that "these activities ... astonish, excite, and distract." 78 While barbecue culture advertised its role in fortifying the individual, it also suggested that public approbation was not only acceptable, but necessary for a successful barbecue and to be a successful chef - "one whose wife has grown good and tired of hearing all his friends tell him how well he can barbecue meat." Recipes that are "a real production" are included to "win acclaim from all" as "they watch the chef perform at the grill."79 In fact, many barbecue books even recommended seating and food arrangements that facilitate a better performance. The Culinary Arts Institute's experts, for instance, recommended one "set appetizer trays where guests can be kept from under foot of the chef but close enough to appreciate his skill in grilling." Similarly, The Complete Barbecue Book counseled barbecue chefs to "remember that a little showmanship goes a long way. Have your audience assembled for that thrilling moment when you remove the steak from the fire to test the color." 80 The emphasis on performance, showmanship, and acclaim redirected the source of security from individual satisfaction to social acceptance, affirming values derided elsewhere as threats to the self, and signaling that individualism was yet another good being sold.

Indeed, much of the 1950s barbecue library reads like an ad selling the tools and accessories needed to achieve social status. ${ }^{81}$ The Hungry Man's Outdoor Grill Cookbook (1954) contained barbecuing hints which were less a how to grill and more a sales pitch to men about achieving middle-class success: "a do-as-you-please grill party will be a conversation piece for days afterward." 82 In a 1946 New York Times article, Grace Mayes notes that advertising is no longer just for women, but that men too are susceptible to "slick advertising campaign[s]" that rely on concerns about appearance and social acceptability ${ }^{83}$ This shift had a significant effect on the nation's advertising, prompting Life to comment, "marketing has become a family affair." Postwar advertisers targeted the American male, for whom, Life reported, "gadget buying is his meat," promising him social acceptance in exchange for his hard-earned dollars. ${ }^{84}$ Gear made the man in barbecue culture, or as Look announced, "it takes just one summer to turn a caveman into an outdoor chef in full 1955 regalia." Thus, evidence of Madison Avenue's gray flannel suits is everywhere in barbecue books, from Paul Swensson's shameless endorsement of Burr-Southern grills and Cliffchar Charcoal Briquets - “Buy them!!!", — to Harold Bartron's promotion of his own line of grills, to James Beard and Helen Evans Brown's inclusion of barbecue suppliers" addresses for consumer ease. ${ }^{85}$ It was evident that the "you" in all of 
the articles announcing "you can build your own barbecue" was male. Barbecue capitalized on advertising's "democratization" and marketed itself as "something for the boys" - a reward for spending long days in the corporate office to provide for the family. ${ }^{86}$

\section{"Tie on your aprons, men!"87}

Not only did postwar barbecue illustrate 1950s America's efforts to secure national identity, but it also reflected the struggle to preserve and protect individual homes. Specifically, barbecue culture strove to secure individual men against perceived changes in gender roles on the domestic front. Postwar barbecue culture compulsively reiterated its manliness, and this is not surprising, for during World War II, government propaganda equated meat with male power, and by extension, national power. ${ }^{88}$ Amy Bentley's landmark study Eating for Victory (1998) demonstrates how wartime America viewed meat as yet another weapon, with army propaganda going so far as to proclaim, "American meat is a fighting food." ${ }^{89}$ Slogans like "Eat The Right Food, U.S. Needs US Strong" aimed to curb domestic appetites and promote good national health. ${ }^{90}$ Rations on the home front meant more meat for the troops and a way of supporting those fighting for America's way of life. Both political and commercial advertisers shifted meat consumption from a want-based to need-based system in which men came first for the good of the nation. ${ }^{91}$ In America, meat was masculine, and in 1950 s America, this masculine "weapon" was used to reassert male primacy in the workforce and home.

Yes, "traditional cooking" did return home with veterans after WWII, but the homes themselves had changed. With the rise of women in the workplace, newly returned GIs felt their position in both public and private sectors threatened. As labor economist Frances Whitlocke has pointed out, women had always worked - whether in the home or in both home and industry; however, WWII changed who and how many worked, increasing both the total number of women workers and the number of middle-class women at work..$^{92}$ In 1949, 46 percent of working women were married, 43 percent of whom had children. In fact, from 1900 to 1950 , the number of women in the workforce had tripled, "increasing from 5.1 million to 18.1 million," and by 1951, 29 percent of the labor force was female. ${ }^{93}$ Many women reported that they were not working for pin money, but stressed that work was "a means of releasing their creative energies" and "just the plain American desire to get ahead'. ${ }^{94}$ Like men, women saw work as a way to express themselves as individuals, to assert their autonomy, and to pursue that American dream. This workplace "invasion," as U.S. News \& World Report called it, was not only seen as threatening to male jobs, but also as destabilizing the structure of home, nation, and the masculine psyche because his "status as the member of the dominant sex is jeopardized." A 1945 New York Times Magazine article sounded the alarm about this destruction, arguing that shifting gender dynamics will "unman the male and undermine his sense of security," ultimately 
leading to national fragility: "Who wants a nation of sniveling broken-spirited weaklings with nothing to show for their manhood but their beards?" The answer to this question, according to a 1946 Fortune survey on women working, was a resounding "no!" The survey "reflected some smoldering resentment" about women working, and it reported that 46 percent of men and 38 percent of women said women "should not" work even if they had no children under sixteen, and 63 percent of men and 57 percent of women said "no" when the children caveat was removed. ${ }^{95}$ What this survey showed was that most postwar Americans saw women's place in the home and that men felt more secure in and at home if this was so.

The hypermasculinity forwarded by postwar barbecue also signals 1950s America's awareness of and anxiety about what Jeffrey Sobal has termed "multiple masculinities" - an anxiety that prompted a singular model to protect man's "proper" space in the political, economic, and domestic spheres. ${ }^{96}$ Whether an actual or imagined crisis, changes in the role of the American male occupied America's consciousness in the postwar period. Arthur Schlesinger, Jr.'s "The Crisis of American Masculinity" (1958), Mills' White Collar (1951), Riesman's The Lonely Crowd, Whyte's The Organization Man, and Packard's The Status Seekers, as well as popular magazines Reader's Digest and Look, announced the breakdown of traditional masculinity, claimed "almost no one is rallying men to . . . make a stand," and clamored to reverse the emasculation of America. ${ }^{97}$ By celebrating what it considered traditional ideals of masculinity, postwar barbecue culture attempted to make a stand and reinstate man as the head of his household, provider of sustenance for his family, and fortifier of his community. Significantly, he did so by reasserting his role as provider in a public space, as opposed to his wife whose primary work is located inside in the kitchen. Yet, before anyone could associate barbecuing with the feminizing power of domestic life, barbecue texts asserted that meat - its acquisition and preparation-has always been male; or as Trader Vic put it, "ever since Adam and Eve pinned fig leaves on one another in the Garden of Eden, man has brought home the bacon" and Eve's "old man is often found hovering over a hot stove or pile of brick in the back yard"98 (see Figure 5). In so doing, Trader Vic and others claimed the barbecue as a space and activity outside of time and the domestic sphere.

Jessamyn Neuhaus, Thomas Adler, and John and Karen Hess all have examined the ways in which the act of cooking and recipes themselves were encoded with gender prescriptions that shaped postwar conceptions of masculinity and femininity. They argue that women were the everyday cooks who were responsible for food and basic family nourishment, whereas men were the weekend warriors who tackled food as a hobby that involved many tools and much leisure time. Women's cookery was a task, whereas men's cookery was a fun spectacle. Or, as the Robersons put it, "inventive cooking is definitely a man's approach to the preparation of food. . . . At this moment in his culinary experiences, he steps smack into the realm of true adventure." These divisions firmly planted women in the home and men outside at the grill, ascribing to Victorian notions 
One Nation Over Coals 25

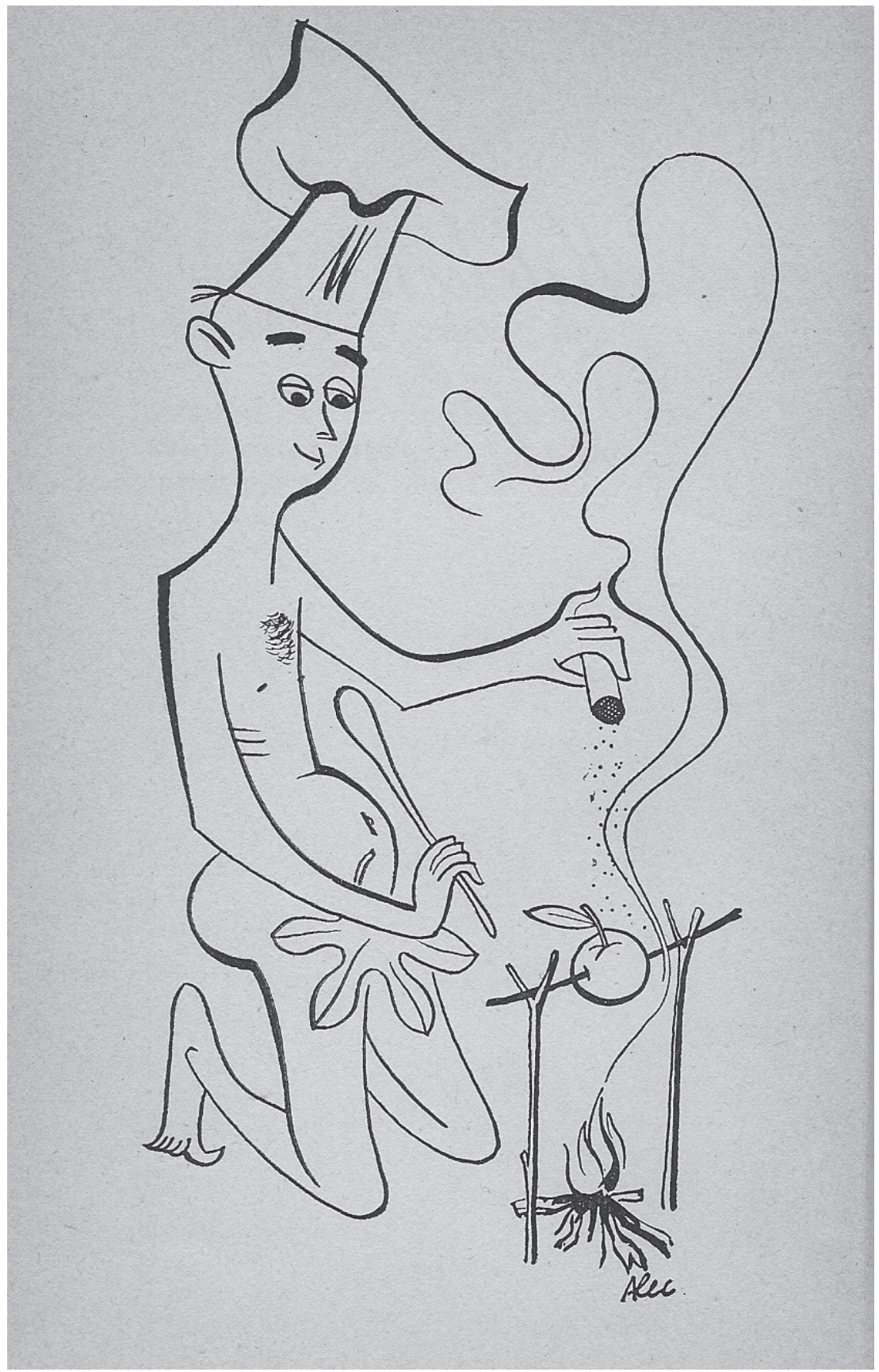

Figure 5: Trader Vic's American Adam barbecuing for his Eve. 
of public/private sphere, and linking such to familial and national security. ${ }^{99}$ Some magazines troubled these gender divisions and placed women at the grill. Look, Popular Mechanics, and American Home all showed women donning the chef's cap, flipping the burgers, and serving up a barbecued meal. These texts and others indicated that women too could dazzle while fortifying the family body; however, this was the exception rather than the rule. More often than not, barbecue culture announced that barbecue "is primarily a man's job and that a woman, if she's smart, will keep it that way."100

Accordingly, barbecue culture offered a vision of the rugged and individualistic provider - the potent patriarch who sees to his family's needs and is rewarded with admiration and obedience. Esquire's Handbook for Hosts (1952) announced that the barbecue is "a masculine contraption, fitten and designed for the male" - a space inherently masculine and "wholly American"; Ashley Simms dedicated his book to the "rugged outdoorsman ... . [and] intrepid he-men"; and Swensson's Patio Partner Barbecue Cook Book crowed that "throughout history, barbecue cooking has been (and definitely is still) 'MAN TYPE' cooking." ${ }^{101}$ McCall's dedicates its barbecue issue to "The Great American Mister who stands, chef's cap on head, fork in hand," American Home's "Charcoal Charlie" trumpets the "new breed of royalty, the charcoal king, the world's best outdoor cook," and Victor Bergen (Trader Vic) writes for House Beautiful that barbecuing is a "noble" and "rugged tradition." 102 These authors emphasize the timelessness of the masculine ideal - individualistic, noble, and adventurous - in attempts to sweep away new masculinities that have cluttered the American domicile. More importantly, in describing this ideal (or as they frame it, "reality"), the barbecue gurus project an ideal American - a rugged man who hearkens back to early settlers, pioneers, and political leaders and intrepidly looks forward to new challenges. This origin myth associates the pioneer hero with the barbecuing male, and the implication is that restoring him to his place will ensure continued national greatness. Images of virile men graced the cover of many barbecue books (like Swensson's) that depicted the chef as a war hero or errant knight, tongs aloft in place of a sword and set upon a pedestal as the object of adoration (see Figure 6). The cover of The Hungry Man's Outdoor Grill Cookbook too displayed the chef as the "hot shot" surrounded by adoring, beautiful, scantily clad women. Although the chef is a balding, middle-aged, overweight man, it is clear that the pin-up girls' appetite is not for the barbecued food alone. These covers evoked a Darwinian survival of the fittest and proposed that the barbecue would make men strong, attractive, and irresistible: "outdoor cookery is a man-sized job. Women never look their best when working over a hot fire; men never look better." 103

The sexual overtones implicit in emphases on meat or being barbecue's big boy signal the undercurrent of anxiety about sexual prowess found in postwar culture and the seeming efforts of barbecue books to assuage this fear even as they invoked it to stimulate sales. These texts tapped into the much discussed public perception that American males were increasingly feminized by working women, corporate culture, and Kinsey Report findings proposing slippery 


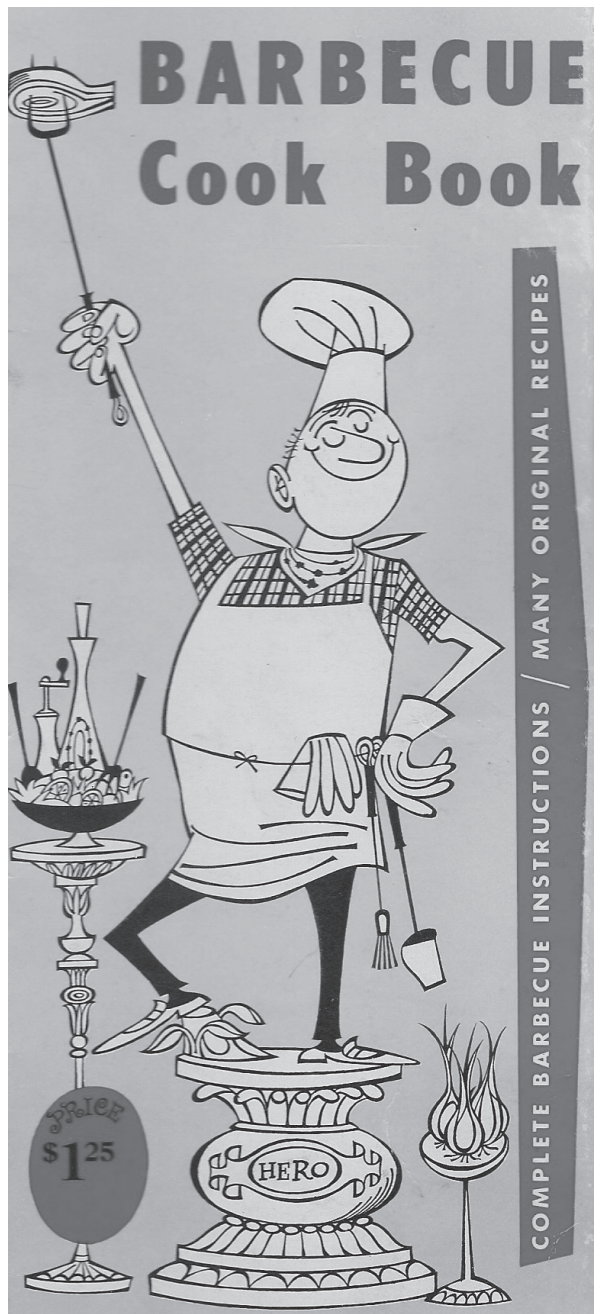

Figure 6: The triumph of the barbecuing male. Used with permission from Robert Caplan and family.

definitions of heterosexuality and homosexuality. ${ }^{104}$ Public concern about gender confusion manifested itself in Look's "The American Male" (1958) which examined men at home, work, and play, and subsequently cautioned: "it is certain that, as women grow even more numerous and more dominant, we will have to invent new meanings and myths for maleness in America, because, as psychiatrist Dr. Irene J. Roselyn warns, 'we are drifting toward a social structure made up of he-women and she-men'. ${ }^{\prime 105}$ Barbecue culture promised that performing various food rituals would stay or even reverse shifting gender constructs because holding and providing meat for one's family - a symbol of power, affluence, and healthputs one in a position of primacy. The assumption made by barbecue culture was that as a barbecue chef, the 1950s American male willed folk to eat what he desired - manly food-controlling what they took into their body, and thereby having some effect on what/who they were. In this way, barbecue was a will to power - a way of shaping the familial and national corpus and transforming oneself in the process: "you'll become a changed man. You will take on a somewhat godlike stature," and more importantly, "as for the ladies—well, they'll virtually be your slaves." 106

This troubling rhetoric of sexual slavery reaffirms meat's function as what Carol Adams has called "a symbol of male dominance," 107 thereby making the postwar man's stand contingent upon implied violence against women. Adams' The Sexual Politics of Meat discusses at length the substitutive value of meat and female sexuality, arguing that the sexual disempowerment and degradation of women relies upon renaming women as an object—meat— to be conquered 
and consumed. This is clear in representations of barbecue's female attendees: the buxom women are "meat" hungrily awaiting the meat cooked by belowaverage men. Nick Fiddes too records the collusion of sex and food in postwar narratives in his book Meat: A Natural Symbol, pointing out that the conflation of bestsellers The Joy of Sex and The Joy of Cooking resulted in the equation of women and meat - a sexually violent act. ${ }^{108}$ Although most of these connections are implied, some periodicals explicitly link women to meat, like Damon Runyon's noir-esque story "Barbecue" in Colliers that called its dame "barbecue," or Willig's article that asks "why is it that the most indolent, undomesticated men, seeing a grill, some charcoal and a piece of raw meat, turn to it as inevitably as they would turn to Marilyn Monroe in a bikini?" 109 In these and similar pieces, women and raw meat were one and the same, and violence is not only evident, but also pleasurable. Barbecue culture clung to a pin-up girl ideology of femininity that hearkened to pre- and WWII stereotypes of gender, suggesting its resistance to the changes that occurred on the domestic front while GI Joe was away. In this particular social order, women were offered few options in terms of roles: they were to look good, to stay in "Mama's kitchen," 110 or to "shoulder behind-the-scenes details to let the chef reign supreme at the grill." 111

Certainly, barbecue culture's hypermasculine ideal protested too much, and it signaled an awareness that the changes in America's domestic structure were not to be undone. The "hunger" for days gone by when men were manly and women were home was countered by the reality that women were working and would continue to do so. Furthermore, despite barbecue culture's efforts to recast barbecue as predating or outside of domestic boundaries, its emphasis on and investment in the home troubled the strict division between public and private spheres upon which conventional notions of gender had been founded.

\section{Conclusion}

"Cool summer evenings ... keen appetites ... glorious fresh air ... wonderful food . . . that's for June. And barbecues never tasted so good," cooed Better Homes \& Gardens in 1950, associating barbecue with all that is "good" and all that is American. ${ }^{112}$ Here and elsewhere, the magazine that typified postwar domesticity equated barbecue with "the good life" and implied all red-blooded Americans were entitled to it - to a life of perfect weather and a backyard in which to enjoy it, to a life surrounded by friends and family, to a life where food is in abundance, and to a life where folk have the leisure time necessary to prepare, eat, and enjoy roasted meats. In so doing, Better Homes \& Gardens and barbecue culture as a whole attempted to stabilize a nation seemingly transforming at a frenetic pace. Ads, books, news reports, and popular culture argued that whether it was communism, suburban isolation, or neighborhood and workforce invasions, the threat facing postwar Americans was no match for the unifying and fortifying power of the barbecue. Of course, this power was contingent upon emulating barbecue culture's model of citizenship - a model based on individual- 
ism, heteronormativity, home ownership, patriotic consumption, status seeking, and community pride. Security was not free, and barbecue culture did its best to tap into the hopes, fears, desires, and values that would ensure folk would buy and buy into its ideal.

Given these aims and practices, 1950s America's barbecue culture easily could be framed as yet another instance of containment culture — of postwar America's efforts to forward a singular, totalizing narrative of Americanness that diffused and delimited difference in order to promote a safe sameness. In fact, Robert Sward's poem "Barbecue," published in Poetry in 1959, makes that charge. The poem reaffirms barbecue's Americanness - not its greatness, but rather its failings, arguing that the codes of consumption, conformity, and heteronormativity associated with barbecue's white middle-class ideal construct an apocalyptic hell on earth that consumes who, what, and where one is, leaving only a superficial unity gained by sipping, eating, and "toasting with one another." 113 The barbecue's attendees are like "moths" drawn to the fire, fluttering about the barbecue and consuming all, including food, drink, and spectacle - " And (again) we clapped one another / Laughed, kissed, sipped, puffed \& swallowed cigarettes." 114 While they "kiss" and "clap" the married hosts, they "bury" Lil, "the wife of no one," and others who do not fit the heteronormative ideal, "beside the spit." 115 Channeling Eliot's Prufrock, the poem's speaker recounts the violence these social codes and conformist rituals enact—people are "choked," "scratched," "pounded," "buried," and "bit[ten]," indicating that no one really is "painlessly / Consumed" or consuming. ${ }^{116}$ Ultimately, the poem charges that barbecue culture's prescribed American ideal was denied to the many, restrictive to the few, and violent to the non-compliant.

Categorizing barbecue as merely another instance or instrument of containment, however, fails to recognize barbecue as the contested site it was-a site where postwar Americans wrestled with competing definitions of nation, self, and other. ${ }^{177} 1950$ s barbecue's aggressive and at times manic insistence on the "typical" barbecuing everyman draws attention to the shaky ground upon which the idealized image of the American barbecuing family stood. Those selling, buying, and reporting on postwar barbecue culture all appeared to be trying too hard to convince others that barbecue made one manly, barbecue facilitated social mobility and made one successful, barbecue made American (read "Anglo") civilization superior, and ultimately, that barbecue was the answer to America's problems. The harder barbecue culture pushed back on changes in the workplace, changes in the home, and changes in social institutions, the more it highlighted those changes. And in protesting too much, barbecue culture inadvertently pointed towards the period's discomfiting realities about race, class, gender, and sexuality. Women were neither "slaves" nor content to stay on the sidelines, but were staying in the paid workforce in sizeable numbers. Racial and ethnic minorities were not absent, but visible and vociferous agitators for civil rights and recognition. And not all postwar men were content to adopt macho masculinity, but instead asserted a range of gender performances and identities. Barbecue culture was 
reacting to something and reclaiming rights from someone, thereby prompting questions of against what and from whom they were responding. Thus, what an examination of $1950 \mathrm{~s}$ barbecue culture ultimately reveals is a phenomena not gastronomical, but rather ontological. What it reveals is a political and social body attempting to come to terms with its multiple, fractious, idealistic, and contradictory self.

\section{Notes}

140.

1. "How to Build a Barbecue in Your Own Backyard," House and Garden 99 (June 1951):

2. Look, "America is Bit By the Barbecue Bug," 19 (July 1955): 57; “Outdoor Cookery: The Inside Story," New York Times Magazine, 16 August 1959: 42 (Hereafter cited as NYTM).

3. There is some debate among foodways scholars as to what can be considered "barbecue." Many, like L. E. Elie, identify "barbecuing" as the slow roasting of meat over coals, as opposed to "grilling" that is defined as other outdoor cookery over charcoal or fire. Encyclopedia of Food and Culture (New York: Scribner, 2003), 164. Implicit in many of these categorizations is a disdain for "grilling" and an elevation of "barbecuing." While the processes of barbecuing and grilling do differ in terms of time and materials, for the purposes of this article, I will use the term "barbecue" to signal both because the primary postwar texts under examination either use those terms interchangeably, or claim outright, as Look did, that "barbecue has come to mean any kind of outdoor cooking meal." Look, "America Is Bit," 57.

4. Ibid.

5. For examples, see Herbert Coggins, "My Barbecue Pit," The Atlantic Monthly 179 (June 1947): 114; and "Midtown Barbecue," The New Yorker, 4 July 1959: 20-1.

6. Examples include "Grilled Barbecuers," Time, 1 June 1959: 18; "Barbecued," Newsweek, 28 December 1959: 16; "GE Directors Eat Southern Barbecue,” Business Week, 13 May 1950: 30; and "Insurance Party: Barbecue for 8,000," Business Week, 12 May 1951: 138-39.

7. A sampling of such articles includes: "Barbecue: An American Art," McCall's 86 (1959): 70-3+; Roberta and John Mofitt, “Outdoor Barbecue Meals!” Good Housekeeping 128 (May 1949): 140-3+; "What's Cooking with Barbecues," Good Housekeeping 130 (June 1950): 79-82; Ellen Anger, "We Barbecue at Home," Parents'Magazine 24 (August 1949): 47-8+; "Barbecue Outfit Folds Into Suitcase," Popular Mechanics 85 (April 1946): 158; Benjamin Nielsen, "Bar-B-Q Cart," Popular Mechanics 89 (June 1948): 178; "This Folding Grill is Outdoor Cook's Delight," Popular Mechanics 108 (July 1957): 165; Paul Corey, "All Play and No Work Built This Barbecue," Popular Science 162 (April 1953): 226-30+; and Sheldon Gallager, "Prefab Fireboxes Make Barbecue Building Easy," Popular Science 168 (June 1956): 157-60.

8. "And What is Summer Without a Barbecue?," American Home (April 1955): 50.

9. Willig, "Outdoor Cookery," 42.

10. As Ripley Hathaway notes, the postwar years demonstrated a boom in barbecue activity as "more articles were written about the barbecue in the $1950 \mathrm{~s}$, in particular in the years 1953 and 1954, than any other time before 1980." Hathaway, "In Xanadu Did Barbecue," in Corn Bread Nation 2, ed. L.E. Elie (Chapel Hill: University of North Carolina Press, 2004), 92, 94. A search of the Reader's Guide Retrospective database revealed that from 1935-1944 there were 27 articles published on barbecue. Those numbers jumped in the postwar period with 141 articles published between 1945 and 1955, or 193 published between 1950 and 1960.

11. Roland Barthes, "Toward a Psychosociology of Contemporary Food Consumption," in Forster and O. Ranum, eds., Food and Drink in History (Baltimore: The Johns Hopkins University Press, 1979), 167.

12. Both McCall's and New York Times Magazine refer to this Art: "The Barbecue: An American Art," McCall's 86 (July1959): 71; Sally Weiner, "The Art of Barbecue," NYTM, 19 July 1953: 24. Look identifies barbecue's unifying power in "America's Big Cook-Out" 18 (July 1954): 56.

13. "Meet the Typical American-Male and Female," Reader's Digest (February 1954): 34.

14. Far from being a reactionary crank, Kenneth Colegrove was a distinguished professor who wrote this "direct look at the realities of life under communism" with the support of the Institute of Fiscal and Political Education, Teachers College at Columbia University, the National Council of the Social Studies, the National Education Association, and several professors from the Ivy Leagues. Kenneth Colegrove, Democracy Versus Communism (Princeton: D. Van Nostrand Company, 1957), 42, 95, 98-9, 97, 101, 104, 105.

15. Ibid., 58. 
16. Brownell is quoted in Ellen Schrecker, Many Are the Crimes (Princeton: Princeton University Press, 1998), 141. Tom Engelhardt, The End of Victory Culture (Amherst: University of Massachusetts Press, 2007); Robert Corber, In the Name of National Security (Durham: Duke University Press, 1993); Schrecker, Many Are the Crimes, 141.

17. Look, "America's Big Cook-Out," 56.

18. "Barbecue Supper!", Better Homes \& Gardens 29 (August 1951): 64.

19. Tested Recipe Institute, Inc., Big Boy Barbecue Book (New York: Grosset \& Dunlap, 1956),

3.

20. Richard Rosen, The Terrace Chef (New York: Richard Rosen Associates, 1952): foreword.

21. “American City Quiz," American City (January 1951): 5; "Our Cities' Role in the National Emergency," American City (1951): 155.

22. Secretary of Defense Charles Wilson, "Don't Underestimate America's Strength," Nation's Business 43 (January 1955): 33; R.E. Baldwin, "How Strong Are We?," American Magazine 146 (1948): 24; James Conant, "Challenge of the Times: A National Philosophy," Vital Speeches 14 (15 August 1948): 644.

23. Both William H. Whyte, Jr.'s The Organization Man (New York: Doubleday Anchor Books, 1956) and David Riesman, et al's The Lonely Crowd (New Haven: Yale University Press, 1950) identified and warned against what they saw as the postwar American man's sacrifice of individuality to corporatism, social conformity, and family. Despite advertising themselves as general cultural analyses of postwar America, both texts primarily emphasized the "condition" of the American male.

24. Sunset Barbecue Book (San Francisco: Lane Publishing, 1945), 5 (emphasis in original).

25. John and Marie Roberson, The Complete Barbecue Book (New York: Bramhall House, 1951), xv.

26. Lizbeth Cohen, Consumer Republic (New York: Vintage Books, 2004), 112-113.

27. Great work has been done on Nixon and Khrushchev's kitchen debates, including: Karal Ann Marling, As Seen on TV (Cambridge: Harvard University Press, 1994); Elaine Tyler May, Homeward Bound (1988); Lary May, Recasting America (1989); and David Halberstam, The 1950s (New York: Random House, 1993).

28. "The Price Problem," Life, 5 May 1947; 32-33.

29. Ibid.: 33 .

30. "Wolfgang Langewiesche, "Everybody Can Own a House," House Beautiful, (1956): 334.

31. Tyler Rogers, "Planning to Build or Buy in 1950?" 129 Parents 'Magazine (January 1950):

90; Langewiesche, "Everybody Can Own," 335; Johnson, "Homeowning Families," 1243.

32. The article too recognizes the downside of the housing boom, noting sprawl, urban decay, and a strained mass transit system as casualties. "Trends to Single Houses Expands Boom," Nation's Business (1955): 32-34.

33. Cited in Richard Lacayo, "Suburban Legend: William Levitt," Time, 7 Dec. 1998: 150. Much was published on Levitt and his vision of American housing in the postwar period. For examples, see: "They'll Build Neighborhoods, Not Houses," Saturday Evening Post, Oct. 28, 1944; "The Six Thousand Houses that Levitt Built," Harper's (Sept. 1948): 11, 43-46; and "What! Live in a Levittown," Good Housekeeping (July 1958): 47, 175-76.

34. "How to Build A Barbecue in Your Own Backyard," House \& Garden (1951): 140; and "Charcoal Charlie," "For Steak Lovers Only," American Home 36 (June 1946): 105.

35. "Here's a Dandy Barbecue Pattern!," American Home 32 (July 1944): 47; "Here's a Barbecue With the Comforts Of Home," House Beautiful 89 (November 1947): 292; "Knockdown Barbecue," Popular Mechanics 97 (June 1952): 173; "What's Cooking With Barbecues? 12 Barbecues You Can Build", Good Housekeeping 130 (June 1950): 79-82; and Herbert Coggins, "My Barbecue Pit," Atlantic Monthly 179 (June 1947): 114.

36. Sunset Barbecue Cook Book (San Francisco: Lane Publishing, 1950), 4 \& 50; and Sunset Barbecue Book, frontispiece.

37. Citing as evidence of democracy's power the claim that "on the shoals of roast beef and apple pie all socialistic Utopias founder," Schlesinger allied America's political health with its food choice, and in this case, meat. Arthur Schlesinger, "Food in the Making of America" in Paths to the Present (New York: MacMillian, 1949), 252; Bob Stahr, "Summer in Your Own Resort," American Home 41 (March 1949): 6; Harold A. Bartron, Barbecue it Right! (Riverside, CA: GoodspeedsPrinters-Lithographers, 1953), 47.

38. American City, "Our Cities' Role," 155.

39. "Leisure Could Mean a Better Civilization," Life (March 1947): 63.

40. It is important to point out that not all articles recognize leisure as the pinnacle of the good life. Sloan Wilson, author of The Man in the Grey Flannel Suit, argues that the "leisure craze" has not cut back on work, nor has it resulted in a "better self," but has perpetuated "self-indulgence," competition, unhappiness, and addictive behaviors. Wilson, "Happy Idle Hours Become a Rate Race," Life (March 1947): 118-123.

41. Jane Nickerson, "Barbecues Are in Season," New York Times, 22 Jun. 1952: SM28.

42. Weiner, "Art of the Barbecue," NYTM: 24.

43. "Barbecue Pointers," House and Garden 85 (June 1944): 94. 
44. Hathaway, "In Xanadu," 92.

45. Laura Shapiro, Something from the Oven: Reinventing Dinner in 1950s America (New York: Viking, 2004), 25.

46. Culinary Arts Institute, Hungry Man's, 8. 26-7; Richard Pillsbury, No Foreign Food (New York: HarperCollins, 1998), 71-2.

47. Tested Recipe Institute, Big Boy, 23.

48. James Beard, "House \& Garden's Barbecue Cook Book," House \& Garden 110 (July 1956): 97

49. Look, "America is Bit:" 57.

50. Roberson and Roberson, Complete Barbecue Book, 3.

51. For a scintillating discussion of food's role in early American politics, see David Waldstreicher's In the Midst of Perpetual Fetes (Chapel Hill: University of North Carolina Press, 1997).

52. Barton, Barbecue it Right!, i.

53. Roberson and Roberson, Complete Barbecue Book, 2; Jim Beard, Complete Book of Barbecue \& Rotisserie Cooking (Indianapolis: Bobbs-Merrill Company, 1954), introduction.

54. Paul Swensson, Patio Partner Barbecue Cook Book (Seattle: University Printing, 1957), 3-4; Tested Recipe Institute, Big Boy, 3.

55. Ibid.

56. Tested Recipe Institute, Big Boy, 14; Sunset, Sunset Barbecue Book, 68; Trader Vic, Kitchen Kibutzer, 25.

57. Architectural Record, "For Better Building": 26.

58. Tyler Stewart Rogers, "Planning to Build or Buy in 1950?": 90; "What House Buyers Are Looking For," U.S. News \& World Report (October 1954): 108.

59. Andrew J. Dunar, America in the Fifties (Syracuse: Syracuse University Press, 2006): 167; Packard, The Status Seekers, 1.

60. Bartron, Barbecue it Right!, 19.

61. Dunar, America in the Fifties, 192.

62. Harry Lorin Binsse, "The House You'll Live In," Commonweal 42 (27 July 1945): 350.

63. Margaret Mead Smith, "Monthly Cost of Owning and Renting New Housing, 1949-50," Monthly Labor Review (1954): 979, 980.

64. Bruno A. Shiro, "Housing Surveys in 75 Cities, 1950 and 1952," Monthly Labor Review (1954): 744.

65. Gabriel Rudney, "Family Income and New Rental Housing," Monthly Labor Review (1951): 12.

66. Mary Carney, "Financing of New Sales Housing in Metropolitan Areas," Monthly Labor Review (1952): 392-94.

67. Kenneth T. Jackson, Crabgrass Frontier (New York: Oxford University Press, 1985), 241. See also Dunar's discussion of race and housing in America in the Fifties.

68. Stephen Meyer, As Long As They Don't Move Next Door (NY: Rowman \& Littlefield, 2000), 89-90, 121, 130-31.

69. Thomas, June Manning and Marsha Ritzdorf, eds., Urban Planning and the African American Community (Thousand Oaks, CA: Sage, 1997), 283.

70. For discussions of African American barbecue culture and traditions, see Jessica B. Harris' "Caribbean Connection" and Robb Walsh's "Texas barbecue in black and white" in Corn Bread Nation 2.

71. Roberson and Roberson, Complete Barbecue Book, 6. This melting out and co-option is strikingly similar to Truman's and Eisenhower's "termination policy" that worked to cancel out Native American reservations, revoke sovereign status, and assimilate tribes into "American" society.

72. Roberson and Roberson, Complete Barbecue Book, 6.

73. Culinary Arts Institute, Hungry Man's, 33.

74. David Riesman, "The Suburban Sadness," in William M. Dobriner, ed., The Suburban Community (New York: G.P. Putnam's Sons, 1958), 380.

75. Whyte, Organization Man, 94-95.

76. Vance Packard, The Hidden Persuaders (New York: David McKay Co., 1957), 57; May, Homeward Bound, 181.

77. John Kenneth Galbraith, The Affluent Society (New York: Mentor Book, 1958), 205.

78. Sunset, Sunset Barbecue Book, 9 (emphasis theirs); and C. Wright Mills, White Collar 1951 (New York: Oxford University Press, 1956), 239, 236.

79. Bartron, Barbecue it Right!, 2; Swensson, Patio Partner Barbecue, 29, emphasis his; Culinary Arts Institute, Hungry Man's, 34; Tested Recipe Institute, Big Boy, 62.

80. Culinary Arts, Hungry Man's, 59; Roberson \& Roberson, Complete Barbecue Book, 26.

81. Chris Dummitt's "Finding a Place for Father: Selling the Barbecue in Postwar Canada" offers an excellent discussion of how postwar barbecue's "commercial speech was a prescriptive discourse" that reinforced false ideals of family and country. Dummitt charges that postwar Canada's barbecue ads and books "assert[ed] a direct relationship between meat, barbecuing, and virile heterosexual masculinity," therein either selling a sexual commodity, or commodifying male sexuality. 
Dummitt, "Finding a Place for Father," Journal of the CHA 9 (1998): 221, 216. Although there are clear parallels between Dummitt's work and my own, his argument's lack of geopolitical consideration signals a key difference. America's postwar position as a superpower embroiled in a battle for world democracy lent its domestic narratives greater urgency and weight, for "security" at home and in the home bore national and international implications. Strong, virile men meant communism's demise within America's borders; anemic men signaled national vulnerability. Whereas Canada sold a domesticated masculinity, America was selling the overall package of global superpower.

82. Culinary Arts Institute, Hungry Man's, 12.

83. Grace T. Mayes, "The American Male Is Okay, But-," New York Times, 12 May 1946:

98.

84. "The New American Male: A Boon to the Household," Life 36 (1954): 42 \& 43.

85. Swensson, Patio Partner, 6 (emphasis his); Barton, Barbecue it Right!, 42-3; and James Beard \& Helen Evans Brown, The Complete Book of Outdoor Cookery (Garden City: Doubleday, 1955), 248.

86. Look, "America is Bit": 58; "Something for the Boys," Better Homes \& Gardens 38 (November 1960): 64.

87. This command can be found in the Better Homes and Gardens Barbecue Book which was typical of the drill-sergeant-like tone 1950s barbecue texts assumed when teaching novices how to be real men.

88. Carol J. Adams' foundational text The Sexual Politics of Meat (New York: Continuum, 1990) deftly maps out the wartime power-dynamics of meat and the ways in which meant became a symbol of male dominance. She then outlines how this wartime battle was normalized in peacetime gender politics. Adams, Sexual Politics, 32-33.

89. See the "Office of Price Administration" pamphlet (Jan. 1943) quoted in Amy Bentley, Eating for Victory: Food Rationing and the Politics of Domesticity (Urbana: University of Illinois Press, 1998), 85.

90. See Mark Graubard, Man's Food, Its Rhyme or Reason (New York: MacMillan, 1943), 7.

91. Bentley, Eating for Victory, 72-4.

92. Frances Whitelocke, "Married Women in Today's Labor Force," Journal of Home Economics 41 (December 1949): 550.

52.

93. "Women Workers_Employment Trends, 1900 to 1950," Monthly Labor Review 72 (1951):

94. "Women in the Labor Force," Business Week, 29 December 1945: 92 and Whitelocke, "Married Women," 551; Captain Dorothy Stratton, "Women After the War," Independent Woman (1945): 295; and Frieda S. Miller, "What's Become of Rosie the Riveter?", New York Times, 5 May 1946: 21.

95. "Wife's Place? More Say 'In A Job'," U.S. News \& World Report, 2 June 1950: 34; Edith Stern, "The Miserable Male," American Mercury (November 1948): 541; Ann Maulsby, "To Keep Them Men," New York Times, 11 February 1945: SM12; and "The Fortune Survey: Women in America," Fortune 34 (August 1946): 8.

96. Sobal argues that "singular masculinity analyses are essentialist perspectives that assume the dominance of one set of male norms in a particular society and historical period that drive and structure men's actions, including food choices, and calls for a new way of discussing masculinities that recognizes multiple, competing, interacting performances of the masculine. Jeffrey Sobal, "Men, Meat, and Marriage: Models of Masculinity," 136 in Food \& Foodways 13 (2005): 135-58. I agree that presenting a single version of masculinity as definitive is problematic for a host of reasons; however, that does not mean that one cannot examine a narrative of singularity forwarded at a particular period that consciously attempts to efface the multiplicities that did exist. The postwar discourses that attempted to normalize the hypermasculine vision of the barbecuing man were not "essentially" dominant; however, barbecue culture tried to claim they were, therein raising an important question: why?

97. J. Robert Moskin, “The American Male: Why Do Women Dominate Him?”, Look, Feb. 4, 1958: 77 .

98. Trader Vic, Kitchen Kibutzer, 11.

99. See Neuhaus' article "Is Meatloaf for Men"; Thomas A. Adler's "Making Pancakes On Sunday: The Male Cook in Family Tradition," Western Folklore 40, no.1, (1981): 45-54; John L. Hess \& Karen Hess The Taste of America (SC, University of South Carolina Press, 1989); and Roberson \& Roberson, Complete Barbecue Book, xv.

100. Beard \& Brown, The Complete Book, 8.

101. Roy Andries DeGroot, ed., Esquire's Handbook for Hosts (New York: Grosset \& Dunlap, 1953), 97.1; Ashley Simms, Epicure and Charcoal (New York: Exposition Press, 1955), frontispiece; and Swensson, Patio Partner, 3-4 (emphasis his).

102. "Bar-b-cue Bonanza," Mc Call's 87 (July 1960): 98; American Home, "For Steak Lovers": 105; Victor Bergen, "Hit Show," House Beautiful 94 (July 1952): 77.

103. Culinary Arts Institute, Hungry Man's, 54. Both Alan Nadel and Barbara Ehrenreich have examined the murky terrain of postwar male sexuality, particularly as it manifest itself in Hugh Hef- 


\section{Kristin L. Matthews}

ner's Playboy that attempted to attempted to relocate male prowess within a firmly consumer space that nevertheless troubled conventional treatments of gender and sexuality. For further discussion of such, see Chapter 5 of Nadel's Containment Culture (Durham: Duke University Press, 1995) and Chapter 4 of Barbara Ehrenreich, Hearts of Men (Garden City: Anchor Books, 1987).

104. Much exciting scholarship has been done in the past decade examining the sociopolitics of "masculinity" during the Cold War. Stand-out studies have expanded the theorization of gender, have problematized the equation of gender with femininity, have challenged the assumption of a singular, dominant maleness, and consequently have sketched a more complex portrait of gender relations in postwar America. See: James Gilbert, Men In the Middle: Searching for Masculinity in the 1950's (Chicago: University of Chicago Press, 2005); Leerom Medovoi, Rebels (Durham: Duke University Press, 2005); Michael Kimmel, Manhood in America (New York: Oxford University Press, 2004); Corber, Homosexuality in Cold War America (1997) and In The Name of National Security (Durham: Duke University Press, 1993); Ehrenreich, Hearts of Men; and Wini Breines, "The 1950s: Gender and Some Social Science," Sociological Inquiry 56.1 (1986). Yet, much of this work places too much faith in postwar America's purported crisis of masculinity, allowing their examination to reinforce the claims made in/by postwar sociological studies that "men" and "maleness" were under attack by women, homosexuals, communists, and corporate culture. In "Men Interminably in Crisis? Historians on Masculinity, Sexual Boundaries, and Manhood," Judith Allen asks why it is that historians have continued to read, write, and accept the narrative that postwar males were suffering from a perceived attack from all quarters of their lives. She asks whether this perpetual crisis might be a sign of privilege and proposes that scholars reexamine this highly politicized narrative. Allen, "Men Interminably in Crisis?", Radical History Review 82 (2002): 191-207.

105. Moskin, "The American Male," 77.

106. Roberson and Roberson, Complete Barbecue Book, 2.

107. Adams, Sexual Politics 33.

108. Nick Fiddes, Meat: A Natural Symbol (London: Routledge, 1991). ery,"46.

109. Damon Runyon, "Barbecue," Colliers 108, 2 August 1941: 11-f; Willig, “Outdoor Cook-

110. Swensson, Patio Partner, 33.

111.Culinary Arts Institute, Hungry Man, 25.

112. Myrna Johnston, "Real bar-b-q flavor!" Better Homes \& Gardens 28 (June 1950): 72, emphasis hers.

113. Robert Sward, "Barbecue," Poetry 94 (May 1959): line 21

114. Ibid., lines 16-17.

115. Ibid., line 37.

116. Ibid., lines 9, 12, 18, 37, 89, \& 3-4.

117. Recent books like Leerom Medovoi's Rebels (2005), Andrew Hobarek's The Twilight of the Middle Class (2005), and Christina Klein's Cold War Orientalism: Asia in the Middlebrow Imagination, 1945-1961 (2003), have demonstrated that the containment narrative that long has defined Cold War studies is but one of many narratives informing our understanding of the postwar period. As Steven Belletto has rightly suggested, the containment critical hermeneutic has in some ways contained how we think about and discuss postwar culture, delimiting the possibility of multiple and conflicting narratives of self and nation. For an extended conversation of the evolution of Cold War studies, see Steven Belletto's "Curbing Containment: Cold War Studies in the Twenty-First Century," Contemporary Literature 48.1 (2007): 150-64. 